\title{
Replied to Role of Marketing Function for Competitive Advantage
}

\author{
S. Sarkum ${ }^{1}$, Supriadi ${ }^{2}$, Abd. Rasyid Syamsuri ${ }^{3}$, Supar Wasesa $^{4}$, Abdurrozzaq Hasibuan $^{5}$ \\ \{ sumitro.ulb@gmail.com ${ }^{1}$, adysupriadi@fe.uisu.ac.id ${ }^{2}$, abd.rasyidsyamsuri@gmail.com ${ }^{3}$, \\ suparwasesa@fe.uisu.ac.id ${ }^{4}$, rozzaq@uisu.ac.id $\left.{ }^{5}\right\}$ \\ ${ }^{1}$ Universitas Labuhanbatu, Indonesia \\ ${ }^{2}$ Economic Faculty, UISU Medan-Indonesia \\ ${ }^{3}$ Economic Faculty, Universitas Muslim Nusantara Al Washliyah, Medan-Indonesia \\ ${ }^{4}$ Economic Faculty, UISU Medan-Indonesia, \\ ${ }^{5}$ Department of Industrial Engineering, Faculty of Engineering, UISU Medan-Indonesia
}

\begin{abstract}
Provide a new perspective on the involvement of dynamic marketing capabilities for sustainable competitive advantage by focusing on three areas of the scientific literature to be studied and integrated into the framework of small companies that can be learned and used in managing digital marketing company. The paper reviews prior literature on Customer Relationship Management (CRM), Social Customer Relationship Management (SCRM), Engagement, and Perspectives on Theory of Dynamic Capability (DC), Dynamic Marketing Capability (DMCs). Dynamic Marketing Engagement is a new concept that is created through a process of reduction of the concept of Dynamic Marketing Capabilities (DMCs) and the concept of Engagement associated with a competitive advantage and competitiveness sustainability. This new concept offers a marketing strategy using digital tools not forgetting offline strategies for identifying, anticipating, managing and winning business competition and studied business in the digital sector, especially for SMEs; thus has implications for the field of academics, practitioners and industry. Combining the three major areas of business research for sustainable competitive advantage, that is Social Customer Relationship Management, Engagement and Marketing Dynamic Capabilities.
\end{abstract}

Keywords: Social CRM; Engagement; Dynamic Capability; Dynamic Marketing Capabilities

\section{Introduction}

Integrating Customer Relationship Management on business operations using information technology as a media tool, building relationships with customers, requiring knowledge of management concepts and transformed comprehensively to all components within the company. Core elements of Customer Relationship Management towards sustainability must be combined with the core elements of sustainability to understand the customer's wishes in accordance with the characteristics and behavior of customers continues to grow. Identifying issues involving the development of marketing with customers to encourage innovation of product creation and improving customer retention sales. Integration of all elements in the Customer Relationship Management can measure and improve the performance of the company. The emergence of social media changing the map of central power with the creation of a customer-centric as a new generation of powerful, sophisticated, difficult to influence, induced and maintained. To deal with these changes, Customer Relationship Management assessment metrics to integrate social media and turned into a social CRM (Customer Relationship Management) as a new paradigm in marketing. To achieve goals and improve 
company performance required customer involvement in implementing marketing strategies in social media. Engagement is a new trend in marketing that first appeared in 1990, develops and talking when social networking media into a marketing tool for many companies to achieve a competitive advantage in the broad market. Engagement also seen to improve the performance of the company to increase sales, create new products and enrich the relationship between the company, employees, customers and supply chains. Finally, all of involvement boils down to the goal of excellence and competitiveness sustainability. The debate between RBV and RBT invited researchers to clarify confusion over less heterogeneity on performance and competitive advantage, while in the literature of the dynamic capability view of the split into three interrelated parts, between the economy, technology and innovation management. Beyond the debate, raised a new term called dynamic marketing capabilities that is based on the development of dynamic capabilities inherent in the organization and are considered to have a high level of value, rare, difficult to imitate and irreplaceable. It is indicated and leads for the purpose of competitive advantage in the ability of organizational competitiveness in the broad market. Dynamic Marketing Engagement is a new concept that is created through a process of reduction of the concept of Dynamic Marketing Capabilities (DMCs) and the concept of Engagement associated with a competitive advantage and competitiveness sustainability. The basic foundation of all renewal based on the incorporation of dynamic capabilities and marketing capabilities in the process involves the role of employees, customers and supply chains in entering and playing the role of marketing in both market linkages between non- and digital. This new concept aims to address significant issues of the role of the marketing function is dynamic and it is hoped will be able to be a marketing guide for SMEs in entering the digital market.

\section{Methodology}

\subsection{Research Design}

The research design adopted in this study is quantitative research in which the data are analyzed statistically by using SPSS 20 . Furthermore, it goes based on the research questions of this research. They are to see the effect of the short course to the students' ability in translating English verbal sentence by considering the improvement of the students' score in the post-test.

\subsection{Sample}

The samples of this research are the students of Senior High School in Medan, Indonesia. It is from Ksatria School. This school has two majors. They are social class and physical class. Both majors are taken to be the samples in this research. However, they are the third year students. There are 14 students in social class and 19 students in physical class.

\subsection{Instrument}

The instrument that is used to collect the data in this research is test. The test is given before and after the short course. Therefore, there is pre-test and post test. The test itself contains verbal sentence in Bahasa Indonesia that should be translated by the students. The questions in the pre-test and post-test are the same questions. Furthermore, the questions are those of basic verbal sentences which contain positive sentence, negative sentence and yes-no question. The pre-test is given to see the problem that might be difficulties for the students. It is seen from the answers of the students. Then the short course is given related to the difficulties found by the students. The researchers call this period is treatment class. The 
treatment class is fulfilled in one day only. Then, the researchers give the students the posttest. It is to see the score of the students. If the score is higher, it means that the short course works well.

\subsection{Data Collection and Analysis}

To collect the data, the researchers give test to the respondents of the research. Therefore, the data is in the form of scores. The score is obtained during the short course. The short course is done separately to both groups with the same treatment.

Table 1. Short Course Schedule for Group A (Social Class).

\begin{tabular}{llll}
\hline No. & Day / Date & Time & Activity \\
\hline 1. & Monday/ 6 February 2017 & $11.00-12.00$ AM & Motivation and Pre - Test \\
\hline 2. & Friday/ 10 February 2017 & $09.15-10.15$ AM & Treatment \\
\hline 3. & Friday / 10 February 2017 & $11.00-12.00$ AM & Post - Test \\
\hline
\end{tabular}

Table 2. Short Course Schedule for Group B (Physical Class).

\begin{tabular}{llll}
\hline No. & Day / Date & Time & Activity \\
\hline 1. & Saturday / 4 February 2017 & $08.15-09.15$ AM & Motivation and Pre - Test \\
\hline 2. & Saturday / 4 February 2017 & $09.15-10.15$ AM & Treatment \\
\hline 3. & Wednesday / 8 February 2017 & $11.00-12.00$ AM & Post - Test \\
\hline
\end{tabular}

From the schedule, it is seen that on the first day, the dominant activity in the class is giving motivation. Motivation is considered really important before giving material or lesson. A research found that motivation in learning is a complex construct because motivation does not come solely from the students themselves, but also from parents, teachers, and social interaction. If all the sources of the motivation are fulfilled, then learning target will be easier to be achieved. However, in Indonesia, the students' motivation dominantly is from random sources, so it is the teachers' task to put them into a good package of motivation to meet the teaching achievement (Wong, 2012). Furthermore, the researchers also give feedback to the students during the short course. Feedback is considered good for students to be better in their learning process. As found by (Irawati and Maharani, 2012) who concluded in her research that teacher's feedback is very good for school students because they still need the intervention from the teacher in their learning process. Furthermore, she also concluded that the combination of correction symbol and conference is effective to be applied. Corrective symbol means that the teacher gives a symbol of the mistake made by the students. Then the student will correct the mistake themselves. Conference means the teacher gives explication and explains the mistake made by the students, and the student correct the mistake themselves.

Table 3. Short Course Schedule for Group B (Physical Class).

\begin{tabular}{lll}
\hline \multirow{2}{*}{ No } & Score & \\
\cline { 2 - 3 } & Pre-Test & Post-Test \\
\hline 1. & 20 & 19 \\
\hline 2. & 12 & 25 \\
\hline 3. & 8 & 13 \\
\hline 4. & 8 & 17 \\
\hline 5. & 7 & 15 \\
\hline 6. & 6 & 15 \\
\hline
\end{tabular}




\begin{tabular}{lll}
\hline 7. & 3 & 15 \\
\hline 8. & 3 & 19 \\
\hline 9. & 3 & 14 \\
\hline 10 & 3 & 21 \\
\hline 11 & 2 & 17 \\
\hline 12 & 1 & 16 \\
\hline 13 & 1 & 18 \\
\hline 14 & 0 & 16 \\
\hline
\end{tabular}

Table 4. Score of Group B (Physical Class)

\begin{tabular}{lll}
\hline & Score & \\
\cline { 2 - 3 } & Pre-Test & Post-Test \\
\hline 1. & 24 & 37 \\
\hline 2. & 16 & 18 \\
\hline 3. & 16 & 30 \\
\hline 4. & 13 & 25 \\
\hline 5. & 12 & 15 \\
\hline 6. & 12 & 12 \\
\hline 7. & 11 & 30 \\
\hline 8. & 10 & 22 \\
\hline 9. & 9 & 13 \\
\hline 10. & 7 & 18 \\
\hline 11. & 7 & 11 \\
\hline 12. & 7 & 27 \\
\hline 13. & 7 & 13 \\
\hline 14. & 5 & 15 \\
\hline 15. & 4 & 20 \\
\hline 16. & 3 & 25 \\
\hline 17. & 3 & 20 \\
\hline 18. & 3 & 22 \\
\hline & &
\end{tabular}

\subsection{Data Normality Test}

Data normality test is utilized to see the distribution of the data. In other words, it is to know that the data are normally distributed. To see the chart of the normal distribution of the data, the researcher adopts the method of Normal Probability Plots in testing the data for both groups. The followings are the charts that show the normal distribution of the data of the two groups in this research. The data distribution are normal because the data spread around the diagonal line of the chart. 


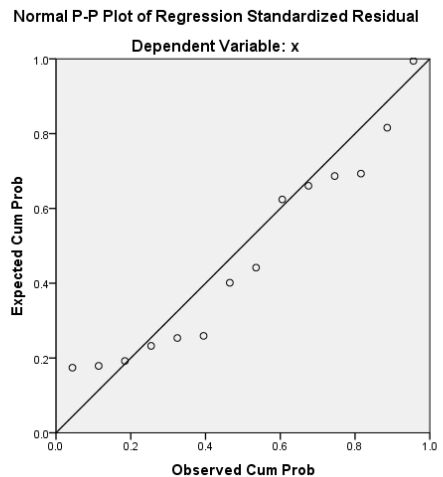

Fig. 1. Chart of data distribution (Normal Probability Plots) of Group A (Social Class).

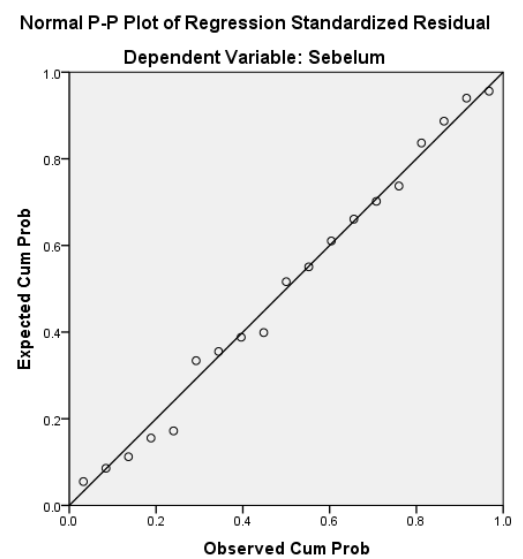

Fig. 2. Chart of data distribution (Normal Probability Plots) of Group B (Physical Class).

To see the normal distribution of the data from the Constanta value or Asymp.sig value, the researcher adopts the method of Kolmogorov-Smirnov Z. Both data show that the Asymp.sig value are larger than 0.05 , then the data are distributed normally. The Asymp.sig value of group A (Social Class) is .343 and .861). And the Asymp.sig value of group B (Physical class) is .757 and .989

Table 5. Group A (Social Class).

\begin{tabular}{llll}
\hline \multicolumn{3}{l}{ One-Sample Kolmogorov-Smirnov Test } \\
\hline & & $\mathrm{x}$ & $\mathrm{x} 1$ \\
\hline $\mathrm{N}$ & & 14 & 14 \\
\hline Normal & Mean & 5.50 & 17. \\
Parameters ${ }^{\mathrm{a}, \mathrm{b}}$ & & & 14 \\
\cline { 2 - 4 } & & 5.374 & 3.1 \\
& Std. & 54 \\
\hline Most Extreme & Deviation & & 34 \\
Differences & & .251 & .16 \\
\hline
\end{tabular}




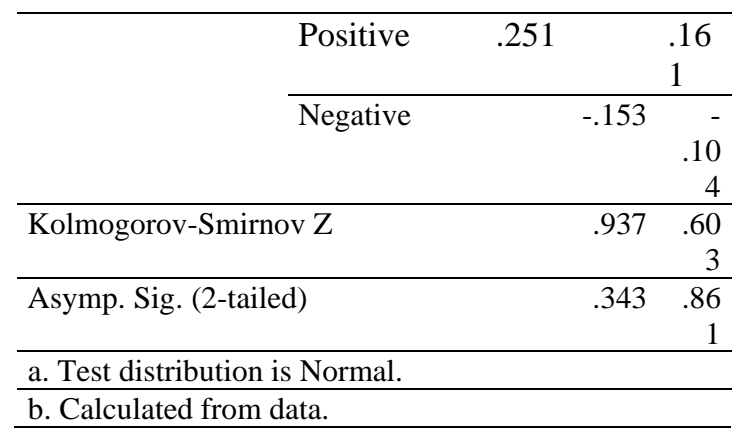

Table 6. Group Bs (Physical Class).

\begin{tabular}{|c|c|c|c|}
\hline \multicolumn{4}{|c|}{ One-Sample Kolmogorov-Smirnov Test } \\
\hline & & $\mathrm{x}$ & $\mathrm{y}$ \\
\hline \multicolumn{2}{|l|}{$\mathrm{N}$} & 19 & 19 \\
\hline \multirow{2}{*}{$\begin{array}{l}\text { Normal } \\
\text { Parameters }\end{array}$} & Mean & 8.89 & 19.63 \\
\hline & $\begin{array}{l}\text { Std. } \\
\text { Deviation }\end{array}$ & 5.811 & 8.480 \\
\hline \multirow{3}{*}{$\begin{array}{l}\text { Most Extreme } \\
\text { Differences }\end{array}$} & Absolute & .154 & .102 \\
\hline & Positive & .154 & .076 \\
\hline & Negative & -.103 & -.102 \\
\hline \multicolumn{2}{|l|}{ Kolmogorov-Smirnov Z } & .672 & .443 \\
\hline \multicolumn{2}{|c|}{ Asymp. Sig. (2-tailed) } & .757 & .989 \\
\hline \multicolumn{4}{|c|}{ a. Test distribution is Normal. } \\
\hline \multicolumn{4}{|l|}{ b. Calculated from data. } \\
\hline
\end{tabular}

Then, the data are calculated by using Wilcoxon Signed Ranked Test because the data in this research is non-parametric data (Prasetyo, 2014). The scores in two groups are calculated separately because they belong to different major.

\section{Result}

\subsection{The Effect of Short Course}

\subsubsection{Group A (Social Class)}

Table 7. Output of Wilcoxon Signed Ranks Test (Rank).

\begin{tabular}{|c|c|c|c|c|}
\hline & & $\mathrm{N}$ & $\begin{array}{r}\text { Mean } \\
\text { Rank }\end{array}$ & $\begin{array}{r}\text { Sum of } \\
\text { Ranks }\end{array}$ \\
\hline \multirow[t]{4}{*}{$\begin{array}{l}\text { Before - } \\
\text { After }\end{array}$} & $\begin{array}{l}\text { Negative } \\
\text { Ranks }\end{array}$ & $1^{\mathrm{a}}$ & 1.00 & 1.00 \\
\hline & $\begin{array}{l}\text { Positive } \\
\text { Ranks }\end{array}$ & $13^{b}$ & 8.00 & 104.00 \\
\hline & Ties & $0^{c}$ & & \\
\hline & Total & 14 & & \\
\hline \multicolumn{5}{|c|}{ a. $y<x$} \\
\hline \multicolumn{5}{|c|}{ b. $y>x$} \\
\hline c. $y=$ & & & & \\
\hline
\end{tabular}


Table 8. Test Statistics.

\begin{tabular}{lr}
\hline \multicolumn{2}{c}{ After - Before } \\
\hline $\mathrm{Z}$ & $-3.235^{\mathrm{b}}$ \\
\hline Asymp. Sig. (2-tailed) & .001 \\
\hline a. Wilcoxon Signed Ranks Test \\
\hline b. Based on negative ranks. \\
\hline
\end{tabular}

\subsubsection{Group B (Physical Class)}

Table 9. Ranks.

\begin{tabular}{llccr}
\hline \multirow{2}{*}{$\begin{array}{l}\text { Before }- \\
\text { After }\end{array}$} & $\begin{array}{l}\text { Negative } \\
\text { Ranks }\end{array}$ & $0^{\mathrm{a}}$ & \multicolumn{1}{c}{$\begin{array}{c}\text { Mean } \\
\text { Rank }\end{array}$} & \multicolumn{1}{c}{$\begin{array}{c}\text { Sum of } \\
\text { Ranks }\end{array}$} \\
\cline { 2 - 5 } & $\begin{array}{l}\text { Positive } \\
\text { Ranks }\end{array}$ & $17^{\mathrm{b}}$ & 90.00 & .00 \\
\cline { 2 - 5 } & & & & \\
\cline { 2 - 5 } & Ties & $2^{\mathrm{c}}$ & & \\
\hline
\end{tabular}

a. After $<$ Before

b. After $>$ Before

c. After $=$ Before

Table 10: Test Statistics ${ }^{\mathrm{a}}$

\begin{tabular}{lll}
\hline \multicolumn{2}{c}{ After - Before } \\
\hline $\mathrm{Z}$ & & $-3.623^{\mathrm{b}}$ \\
\hline
\end{tabular}

Asymp. Sig. (2-tailed) $\quad .000$

a. Wilcoxon Signed Ranks Test

b. Based on negative ranks.

\subsection{The Students' Score before and after the Short Course}

\subsubsection{Group A (Social Class)}

Table 11.The Interval of the Students' Score.

\begin{tabular}{|c|c|c|c|}
\hline \multirow[t]{2}{*}{ No. } & \multicolumn{2}{|c|}{ Score } & \multirow{2}{*}{$\begin{array}{c}\% \\
\text { Interval } \\
\end{array}$} \\
\hline & Pre-Test & Post-Test & \\
\hline 1. & 20 & 19 & $0 \%$ \\
\hline 2. & 12 & 25 & $32.5 \%$ \\
\hline 3. & 8 & 13 & $12.5 \%$ \\
\hline 4. & 8 & 17 & $22.5 \%$ \\
\hline 5. & 7 & 15 & $20 \%$ \\
\hline 6. & 6 & 15 & $22.5 \%$ \\
\hline 7. & 3 & 15 & $30 \%$ \\
\hline 8. & 3 & 19 & $40 \%$ \\
\hline 9. & 3 & 14 & $27.5 \%$ \\
\hline 10. & 3 & 21 & $45 \%$ \\
\hline
\end{tabular}




\begin{tabular}{cccc}
\hline \multirow{2}{*}{ No. } & \multicolumn{2}{c}{ Score } & $\%$ \\
\cline { 2 - 4 } & Pre-Test & Post-Test & Interval \\
\hline 11. & 2 & 17 & $37.5 \%$ \\
\hline 12. & 1 & 16 & $37.5 \%$ \\
\hline 13. & 1 & 18 & $42.5 \%$ \\
\hline 14. & 0 & 16 & $40 \%$ \\
\hline
\end{tabular}

\subsubsection{Group B (Physical Class)}

Table 11. The Interval of the Students' Score.

\begin{tabular}{lccc}
\multirow{2}{*}{ No. } & \multicolumn{2}{c}{ Score } & $\%$ \\
\cline { 2 - 4 } & Pre-Test & Post-Test & Interval \\
\hline 1. & 24 & 37 & $32.5 \%$ \\
\hline 2. & 16 & 18 & $7.5 \%$ \\
\hline 3. & 16 & 30 & $10 \%$ \\
\hline 4. & 13 & 25 & $55 \%$ \\
\hline 5. & 12 & 15 & $7.5 \%$ \\
\hline 6. & 12 & 12 & $0 \%$ \\
\hline 7. & 11 & 30 & $47.5 \%$ \\
\hline 8. & 10 & 22 & $30 \%$ \\
\hline 9. & 9 & 13 & $10 \%$ \\
\hline 10. & 7 & 18 & $27.5 \%$ \\
\hline 11. & 7 & 11 & $10 \%$ \\
\hline 12. & 7 & 27 & $50 \%$ \\
\hline 13. & 7 & 13 & $15 \%$ \\
\hline 14. & 5 & 15 & $25 \%$ \\
\hline 15. & 4 & 20 & $40 \%$ \\
\hline 16. & 3 & 25 & $22 \%$ \\
\hline 17. & 3 & 20 & $42.5 \%$ \\
\hline 18. & 3 & 22 & $47.5 \%$ \\
\hline & & &
\end{tabular}

\section{Analysis}

From the result of the Wilcoxon Signed Ranks Test, it is analyzed that the alpha value of both groups are less than 0.05 . The Test Statistics shows that the alpha value at Asymp.Sig. (2-tailed) of group A (social class) is .001, and the alpha value of group B (physical class) is .000 . This result means that the hypothesis is rejected.

In other words, that there is significant difference of the students' score before and after the short course. Based on the score before and after the short course of both groups, it is analyzed that the score of the students in group A (social class) increased up to $31.5 \%$, and the score of the students in group B (physical class) also increased up to $28.2 \%$.

\section{Conclusions}

The analysis of the statistical calculation infers that there is significant effect of the short course to the students' ability in translating English verbal sentences. Furthermore, the short course is able to reduce the students' error in translating English verbal sentence. In other 
words, the short course affects significantly the students' ability in translating English verbal sentence that is proved by the increase of their score after the short course. It implies that they reduce making error in translating English verbal sentence.

\section{Recommendation}

The conclusion of this research shows us that the short course works well to improve the students' ability in translating English verbal sentences. Therefore, it is recommended that this short course might be conducted with other students. In other words, a short course is potential enough to improve the students' knowledge, especially of English language. As seen in the schedule of the short course, it only needs three days. In these days, the researchers start the class with giving motivation, pre-test, treatment, and post-test. The content or the material in the short course might be different. It depends on the need in the field. Hopefully, this research contributes much for other research, especially those that are related to English language teaching.

\section{References}

[1] Irawati, I and Maharani, L. (2012) 'Teaching And Learning Writing Using Teacher's Written Feedback And Conference.', Register Journal, 5(1), pp. 121-145. Available at: http://dx.doi.org/10.18326/rgt.v5i1.\%25p.

[2] Prasetyo, B. (2014) Metode Penelitian Kuantitative: Teori dan Aplikasi. Jakarta: PT. RajaGrafindo Persada.

[3] Wong. R.M.H. (2012) 'Linking Motivation and Pedagogi: The Case of Newly-Arrived Hong Kong Students.', The Asia-Pacific Education Resercher, 21(3), pp. 636-647. Available at: https://ejournals.ph/article.php?id=4541. 